\title{
The Effects of Various Essential Oils as Antibacterial Agents on Fresh-Cut Apples cv. 'Manalagi'
}

\author{
DOI: 10.18196/pt.2018.087.106-115
}

\author{
Nafi Ananda Utama \\ Department of Agrotechnology, Faculty of Agriculture, Universitas Muhammadiyah Yogyakarta, \\ Jl. Brawijaya, Kasihan, Bantul Yogyakarta 55183, Indonesia, Telp: +62 274 387656, Faks: +62 274387646 \\ email: nafi@umy.ac.id
}

\begin{abstract}
The fast-paced lifestyle of modern consumers warrants the need for a quick and minimally processed food. For fresh products, this means healthy fresh food, convenient, and microbiologically safe food items produced with environmentally friendly methods. In this research, antimicrobial effects of carboxymethyl cellulose based-edible film containing different concentrations of essential oils ( $0.7 \%$ cinnamon, $0.7 \%$ lemongrass, $3 \%$ lemon, and $0.1 \%$ betel, w/v) as antibacterial agents on fresh-cut apples cv. Manalagi were studied. Measurements of weight loss, total titratable acidity (TTA), reducing sugar, microbial growth and sensory quality were determined at 0, 3, 6, 9, 12 and 15 days of storage $\left(4 \pm 1^{\circ} \mathrm{C}, 75 \pm 10 \% \mathrm{RH}\right)$. The results of the research showed that the application of $0.7 \%$ lemongrass oil on $1 \%$ CMC gave the best result in inhibiting the bacterial growth and prolong the storage life of fresh-cut apples cV. Manalagi. The incorporation of $0.7 \%$ (w/V) lemongrass and lemon $3 \%(\mathrm{~W} / \mathrm{V})$ in coating formulation maintained the sensory scores (aroma and appearance) of fresh-cut apples during nine days of storage.

Keywords: Fresh-Cut Apple cv. 'Manalagi', Antibacterial Agents, Essential Oils, Edible Coating, CMC
\end{abstract}

\section{ABSTRAK}

Gaya hidup modern konsumen yang serba cepat membutuhkan kesediaan produk cepat saji dan terolah minimal. Untuk produk segar, hal ini berarti tingkat kesehatan, nyaman, aman secara mikrobiologis serta diproduksi dengan metode yang ramah lingkungan sangat penting diperhatikan. Pada penelitian ini, efek antimikrobia dari edible coating berbahan dasar carboxymethyl cellulose yang diperkaya berbagai macam minyak atsiri (0,7\% kayu manis, 0,7\% sereh, 3\% lemon, 0,1\% sirih) pada fresh-cut apel var. Manalagi diteliti. Pengujian berupa susut bobot, total asam tertitrasi, gula reduksi, pertumbuhan mikrobia dan kualitas sensori dilakukan pada 0, 3, 6, 9, 12, dan 15 hari penyimpanan. Hasil penelitian menunjukan bahwa pemberian 0,7\% atsiri sereh ada 1 \% CMC memberikan hasil terbaik dalam menghambat pertumbuhan bakteri dan memperpanjang umur simpan fresh-cut apel var. manalagi. Kombinasi antara 0,7\% atsiri sereh dan 3\% atsiri lemon pada larutan coating dapat mempertahankan nilai sensori pada fresh-cut apel hingga hari ke-9 penyimpanan.

Kata Kunci: Fresh-Cut Apple cv. 'Manalagi', Antibacterial Agents, Essential Oils, Edible Coating, CMC

\section{INTRODUCTION}

With the advancement of technology, the public demand for a high quality of fresh, practical and quick-served horticultural products has opened various technological opportunities for fresh-cut products. In today's fast-paced society, people tend to prefer food with minimum preparation time. Thus, they choose to consume fruits that are not messy, easy to prepare, and readily edible on the go (Harker et al., 2003). IBIS World Industry Report projected that the fresh-cut fruits and vegetable industry would increase by $2.8 \%$ each year, culminating to a total worth of US $\$ 6.8$ Billion in the next five years (Carvalho et al., 2016).

Apple is one of the most popular horticultural commodities because of its sweetness, high water content, and high nutritional value. Various variet- ies of apples have been developed in Indonesia, one of which is called 'Manalagi'. Despite their high nutritional value, processed apples have a shorter shelf-life due to faster fruit browning, increase in respiration and ethylene production, changes in taste, forming of secondary metabolites, and the increase of microbial growth (Brecht 1995, Olivas, Mattinson et al. 2007). Processed apples also tend to lose their weight faster because of the increased surface area and the removal of the peel, which delays water content loss and functions as a protection measure from the environment. One option to reduce quality deterioration from the processing of fresh-cut fruits is with an edible coating by applying a thin film of material to reduce respiration and water content loss. This creates an artificial layer 
that reduces decay, delays the ripening process, as well as improves appearance, sales value, and nutritional content (Olivas, et al., 2007; Guerreiro et al., 2015).

Carboxymethyl cellulose (CMC) is the most commonly used cellulose in the food industry because it has some beneficial properties (Dashipour et al., 2014). CMC is a type of cellulose derivative widely used in various applications such as food coating, emulsifying, stabilizing, and preventing water evaporation. It is made of 56 linear chains of beta (1-4) glucosidic units added with methyl and carboxyl substituents (Raeisi et al., 2015). The film created from CMC is strong with a high level of water vapour permeability due to its hydrophilic properties. Compared to other biopolymers, however, $\mathrm{CMC}$ does not possess antimicrobial properties (Ponce et al., 2008). Therefore, it must be improved with other substances that have antimicrobial properties like essential oils.

Recently, natural antimicrobial agents have been seen as a potential candidate to replace chemical agents. CMC and other biopolymers are suitable for natural antimicrobial and antioxidant compounds (Cava-Roda et al., 2012; Jo et al., 2014) and can be processed to become edible coating to preserve fruit quality and increase storage life (Salmieri and Lacroix, 2006; Ponce et al., 2008; Vu et al., 2011).

Based on a study conducted by Raeisi et al. (2015), edible film coating made from 1\% CMC added with Zataria multiflora essential oil managed to extend the lifespan of food items. Treatment of $1 \% \mathrm{CMC}$ added with ascorbic acid will reduce the browning process on sliced apples (Saba and Sogvar, 2016). Raybaudi-Massilia et al. (2016) stated that application of antimicrobial edible coating may prevent microbial contamination, lengthen the shelf-life of food items, and repair the quality of food items.
Research conducted by Raybaudi-Massilia et al. (2008) found that the application of alginic acid such as with cinnamon, lemongrass, and betel of $0.7(\mathrm{v} / \mathrm{v})$ and cinnamaldehyde, eugenol, and citric oil of 0.5 (v.v) on fresh-cut apple may inhibit microbiotic growth for 30 days and reduce $>4 \log$ CFU/g E. coli 015:h7 on the first week of its shelflife. Another research conducted by (Perdones et al., 2012) showed that Chitosan added with 3\% lemon essential oil may be used as a fungal deterrent on strawberries for its shelf-life. Prakash et al. (2010) found that the application of essential oil based on betel leaves with a concentration of 0.1. $0.2 \%$ performed better to inhibit microbial growth and reduce antioxidants when compared to other essential oils.

This research was performed to analyze the effectiveness of adding various essential oils to CMC and to determine the best-performing essential oil to be used as antibacterial agent for fresh-cut apples cv. Manalagi.

\section{MATERIALS AND METHOD}

Slicing

Apples cv. "Manalagi" of the same rioening stage and size were harvested from an orchard at Malang, East Java, and stored at 4 degrees Celsius. The fruits were rinsed with a 200 L-1 sodium hypochlorite solution, dried and cut into six slices weighing between 11 to 12.5 grams. The coating solutions were made by dissolving CMC in distilled water (1\% w/v) which was then heated to 90 degrees Celsius for thirty minutes. As a plasticizer, glycerol (1.5\% $\mathrm{w} / \mathrm{v}$ ) was mixed into the solution and stirred. The fruit slices were dipped into the solution for three minutes with these parameters: Control: distilled water, Treatment 1: 1\% CMC, Treatment 2: 1\% $\mathrm{CMC}+0.7 \%$ cinnamon essential oil, Treatment 3: $1 \% \mathrm{CMC}+0.7 \%$ lemongrass, Treatment $4: 1 \%$ $\mathrm{CMC}+3 \%$ Lemon and Treatment 6: 1\% CMC 
$+0.1 \%$ piper betel leaves. Each treatment was repeated three times resulting in a total of 18 experimental units. Each experimental unit consisted of 1 untreated apple slice as a control sample and 6 treated apple slices. After the treatment was given, each sample was given a bacteria isolated from rotten apple flesh and then placed in polystyrene boxes, and stored at 4oC.

\section{Antimicrobial testing}

The antimicrobial testing was done by testing the inhibition rate using paper disc $(\mathrm{cm})$. The testing of antibacterial properties is done to find out various essential oils' ability to inhibit rot-causing bacteria on fresh-cut apples. Paper discs with $1.2 \mathrm{~cm}$ diameter were dipped in each essential oil solution, then placed in Petri dishes with isolated rot-causing bacteria and incubated for 48 hours. After the incubation period, an inhibitory zone appeared and it was measured by observing the formed clear zone. Various essential oils were added to NA media and placed in Petri dishes. The microbial stock was mixed with $1 \mathrm{ml}$ of medium and incubated for 48 hours. The inhibitory properties were measured by the number of bacteria in the medium.

\section{Coating Solution Preparation}

Ten grams of CMC were mixed with $1000 \mathrm{ml}$ aquades to create $1 \% \mathrm{CMC}$ solution. The solution was homogeneously stirred and heated on 900C. $1.5 \%$ Glycerol was added to the solution as a plasticizer, then homogeneously stirred on $900 \mathrm{C}$. After the CMC solution is formed, essential oil of various concentrations according to the treatments was added. When the solution was homogenous, the coating was ready to be applied.

\section{Coating Application}

Apples were washed with a solution of water and 200 microliters/liter of chlorine. Cleaned apples were sliced into six crescent-shaped slices weighing 11-12.5 grams each. The cutting of the fruit used stainless steel knives. The sliced apples were dipped in cold water to prevent browning. Then, the apples were dipped into the CMC and essential oil solutions until they are fully coated. After drying, the apple slices were sprayed with the bacterial solution and packaged using Styrofoam and wrapping plastic before stored in a cooler with a temperature of $40 \mathrm{C}$.

\section{Weight loss}

Weight loss of sliced apple was measured on day $0,3,6,9,12$, and 15 of observation by weighing 18 samples during the 15 days of storage compared with their initial weights by using a digital balance (Ohaus SPS 402S, USA) and the results was presented in a percentage (Horwitz 2000).

\section{Total titratable acidity}

Acidity percentages were measured by titration. 5 grams of pureed fruits were dissolved in $100 \mathrm{ml}$ aquades. $10 \mathrm{ml}$ of the filtration was then taken and placed in an Erlenmeyer flask and mixed with 1-3 drops of PP indicator. The solution was then titrated with $1 \mathrm{~N} \mathrm{NaOH}$ until the color turned pink (Horwitz 2000).

\section{Reducing sugar}

The reducing sugar level test was done five times on day $0,3,6,9,12$, and 15 . The testing used the Nelson Somogyi test (Somogyi 1952), where the reducing sugar reduces $\mathrm{Cu} 2+$ ions to $\mathrm{Cu}^{+}$, to form a greenish blue complex, in which its intensity was measured using a spectrophotometer (Thermo, Genesis 30, USA) on a $540 \mathrm{~nm}$ wavelength.

\section{$\mathrm{pH}$}

The $\mathrm{pH}$ value was measured using a $\mathrm{pH}$ meter (Lovibond, SensoDirect pH110, Germany). Before 
the test, $\mathrm{pH}$ meter electrodes were standardized using a buffer solution, then cleaned using aquades and dried.

\section{Sensory analysis}

The sensory analysis was done on day $0,3,6$, 9, 12, 15 and included a taste panel formed by 15 panelists on the base of a 9-point hedonic scale: 1 Dislike extremely; 2-Dislike very much; 3-Dislike moderately; 4-Dislike slightly; 5- Neither like or dislike; 6-Like slightly; 7-Like moderately; 8-Like very much; 9- Like extremely (Stone et al., 2012). Sensory variables evaluated were appearance and flavor. The Panelists for these tests were faculty students and staff, all of whom have been trained to become familiar with the fruits.

\section{Statistical analysis}

The observed data were analyzed using Analysis of Variance (ANOVA) at 5\%. Should visible differences between the treatments were found, then

Table 1. Bacteria Identification

\begin{tabular}{lll}
\hline No & Identification & Bacteria \\
\hline 1 & Color & Milky white \\
2 & Diameter & $0.2 \mathrm{~cm}$ \\
3 & Colony shape & Circular \\
4 & Edge shape & Entire \\
5 & Inner structure & Smooth \\
6 & Elevation & Law confex \\
7 & Aerobicity & Facultative Anaerob \\
8 & Gram characteristic & Positive (Purple) \\
9 & Cell shape & Coccus-streptococcus \\
\hline
\end{tabular}

Table 2. Antibacterial Inhibition Rate Using Paper Disc Method

\begin{tabular}{ll}
\hline Treatment & Inhibition Rate $(\mathrm{cm})$ \\
\hline Control & $0.00 \mathrm{~b}$ \\
Cinnamon $0,7 \%$ & $1.53 \mathrm{a}$ \\
Lemongrass $0,7 \%$ & $1.93 \mathrm{a}$ \\
Lemon $3 \%$ & $1.57 \mathrm{a}$ \\
Betel $0,1 \%$ & $1.60 \mathrm{a}$ \\
\hline
\end{tabular}

Note: Values within column with different letters are significantly different $(P<0.05)$. another test using Duncan's Multiple Range Test (DMRT) was performed.

\section{RESULTS AND DISCUSSION}

Isolation and Identification of Apple-Rotting Bacteria

According to the results of the identification shown in Table 1, the bacteria in the fresh-cut apple fruits were lactic acid bacteria. This is in line with the identification performed by Holt et al. (2000) to lactic acid bacteria, where the macroscopic bacteria were milky white and round with edges, with a smooth inner structure and law convex elevation. Meanwhile, the microscopic identification showed purple bacterial cells and conjoined round shapes. According to Casida (1968), lactic acid bacteria can grow with or without oxygen.

Antibacterial Inhibition Rate Testing with Paper Disc Method

Table 2 shows that essential oil has a strong antibacterial inhibition rate when applied to freshcut apples. However, there was no visible difference between various types of essential oil. The strongest inhibition rate was shown by $0.7 \%$ betel essential oil with a $1.93 \mathrm{~cm}$ inhibition diameter

Essential oils are made of a multitude of components, some of which targets the bacterial cell. The hydrophobic properties of essential oils allow them to partition in the cell membrane and mitochondria, which makes them permeable and turns the cell vulnerable to leakage (Burt 2004). According to Bakkali et al. (2008), essential oil can terminate bacteria by changing their cell membrane's permeability, taking away the ions in the cell, inhibiting proton pump, and lowering the production of Adenosine Triphosphate (ATP). The lipophilic essential oil can bypass bacterial cell walls because the walls are made of polysaccharide, fatty acids, and phospholipid. This causes the damage to cell walls which kills the bacteria. 
Planta Tropika: Jurnal Agrosains (Journal of Agro Science) Vol. 6 No. 2 / August 2018

Table 3. Sensory Evaluation of Frechcut Apple Covered with Different CMC Based Edible Coating Formulation During Storage at $4^{\circ} \mathrm{C}$ and $85 \% \mathrm{RH}$

\begin{tabular}{|c|c|c|c|c|c|c|c|}
\hline & Days & Control & CMC 1\% & $\begin{array}{c}\text { CMC 1\%+ } \\
\text { Cinnamon 0.7\% } \\
\end{array}$ & $\begin{array}{c}\text { CMC1 } \%+ \\
\text { Lemongrass } 0.7 \% \\
\end{array}$ & $\begin{array}{c}\text { CMC } 1 \%+\text { Lemon } \\
0.7 \% \\
\end{array}$ & $\begin{array}{c}\text { CMC1\% + Bete } \\
0.7 \% \\
\end{array}$ \\
\hline \multirow[t]{6}{*}{ Appearance } & 0 & 6.894 & 7.74 & 6.894 & 7.74 & 6.894 & 6.3 \\
\hline & 3 & 6.3 & 6.3 & 6.606 & 6.3 & 6.606 & 3.906 \\
\hline & 6 & 4.5 & 5.706 & 5.706 & 5.706 & 6.3 & 3.6 \\
\hline & 9 & 3.6 & 4.806 & 4.806 & 4.806 & 5.706 & 3.6 \\
\hline & 12 & 3.6 & 4.5 & 4.5 & 4.5 & 5.4 & 1.8 \\
\hline & 15 & 2.106 & 2.394 & 2.7 & 2.7 & 4.806 & 1.8 \\
\hline \multirow[t]{6}{*}{ Aroma } & 0 & 9 & 9 & 9 & 9 & 9 & 6.3 \\
\hline & 3 & 5.994 & 6.966 & 6.894 & 6.3 & 6.894 & 3.906 \\
\hline & 6 & 5.094 & 5.094 & 5.4 & 5.4 & 6.606 & 3.906 \\
\hline & 9 & 4.194 & 4.194 & 5.4 & 5.4 & 6.3 & 3.294 \\
\hline & 12 & 3.6 & 4.194 & 3.6 & 5.4 & 5.994 & 3.006 \\
\hline & 15 & 3.294 & 3.294 & 2.106 & 4.806 & 4.806 & 1.8 \\
\hline
\end{tabular}

Cinnamon essential oil has two active antibacterial essences: Cynameldyhide and Phenol (eugenol). The two antibacterial essences work by this effect could be attributed to the increased membrane fluidity, damaging the bacteria's protein cells and disrupts the cell membrane or deactivating certain enzymes(Inna et al., 2010; Cava-Roda et al., 2012). In addition, betel has been proven to contain carbohydrate, protein, polyphenolic compounds, flavonoid, alkaloids as well as total antioxidants. Betel's antibacterial properties come from its geranial and neral components (Datta et al., 2011; Nisaaâ and Darjono 2018). Its inhibition mechanism comes from its ability to damage the lipid bilayer cell membrane because of its hydrophobic properties (Lopez-Romero et al., 2015).

\section{Total bacteria test}

The first picture showed that on day 9, bacteria numbers on the control sample had reached its' exponential or logarithmic phase, while the other treatments still show the lag phase. On day 12 , the bacterial growth of all samples is shown to be in its exponential or logarithmic phase. How- ever, on the control sample and on the sample with $1 \% \mathrm{CMC}+0.7 \%$ cinnamon treatment, the bacterial growth rate has reached the peak of its exponential phase, with the control sample having the highest bacterial population.

Based on Figure 1, the addition of CMC coating reduced bacterial growth on fresh-cut apples. The most significant effect was shown by the sample with $1 \% \mathrm{CMC}+0.7 \%$ lemongrass. Based on phytochemical research done by Nambiar (2012), lemongrass essential oil extract contained saponin and tannin. Both substances are used to reduce bacterial growth by damaging bacterial cell wall and changing the components that make up bacterial cells. In addition, lemongrass oil contains 1.8-cincole, geranial, neral, nerol, borneol, linalool, cinnamaldehyde, carvacrol, geraniol, myrtenal, and eugenol, substances acting as antimicrobial agents (Maizura et al., 2007; Vazirian et al., 2012).

\section{Weight loss}

In Figure 2, the control sample experienced more weight loss than samples that were given the CMC coating. The absence of coating treatment 


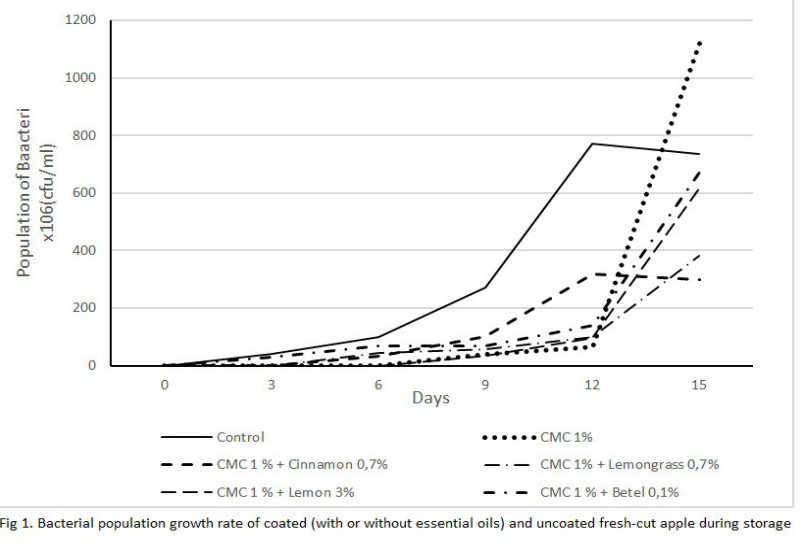

Figure 1. Bacterial Population Growth Rate of Coated (With or Without Essential Oil) and Uncoated Fresh Cut Apple During Storage

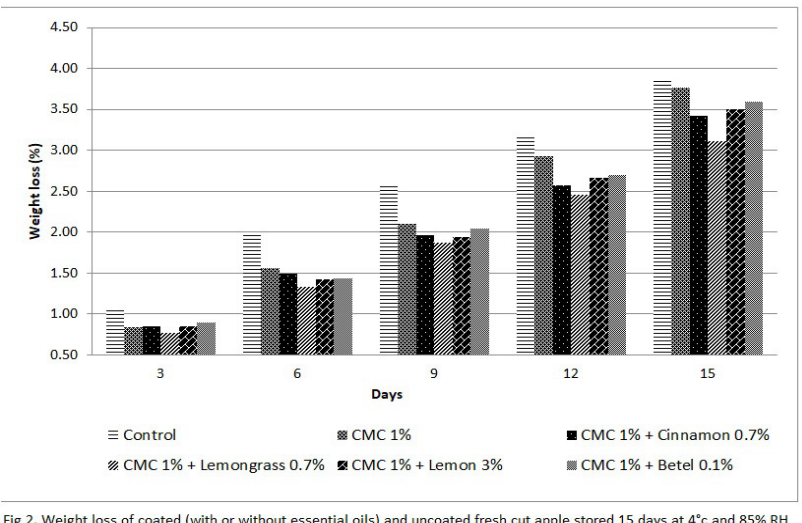

Figure 2. Weight Loss of Coated (With or Without Essential Oil) and Uncoated Fresh Cut Apple Storage at $4{ }^{\circ} \mathrm{C}$ and $85 \%$ $\mathrm{RH}$

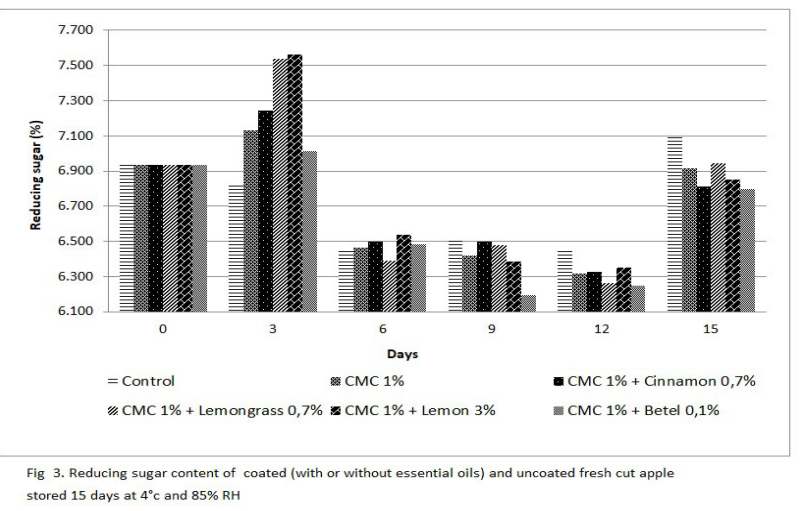

Figure 3. Reducing Sugar Content of Coated (With or Without Essential Oil) and Uncoated Fresh Cut Apple Storage at $4{ }^{\circ} \mathrm{C}$ and $85 \% \mathrm{RH}$

enables the transfer of Carbon Dioxide, Oxygen, and water, which increases fruit respiration rate and a higher water content loss. Samples with $\mathrm{CMC}$ edible coating experienced reduced water content loss.

The addition of $1 \% \mathrm{CMC}$ and $0.7 \%$ lemongrass on fresh-cut apples may reduce the high weight loss. It can be surmised that in this context, bacteria caused the fruit's weight loss. Bacterial attacks may induce stress in fruit. The experienced stress will increase its expiration rate. Therefore, respiration rate is proportionate to stress level (Kader 2002). Weight loss during fresh-cut apple storage can be caused by transpiration and respiration process. According to Kader (2002), respiration process involves the burning of sugar content which produces Carbon Dioxide, water, and energy in the form of heat. Gardjito and Swasti (2017) clarified that heat produced by the respiration process caused an increase of temperature on the fruit's tissue. A high tissue temperature leads to a higher difference in pressure between the fruit and its surroundings. The higher the difference, the faster the exchange of evaporated water content will be.

\section{Reducing Sugar}

According to the reducing sugar histogram in figure 3 , the average rate of reducing sugar on every treatment has experienced fluctuations. From day 0 to day 3, all treatment experienced an increase in reducing sugar levels. This is caused by the increase in respiration rate on fresh-cut apples. The mechanical cutting on apples caused an increase in cell activity in the cut, which in turn increases the respiration rate of the fruit.

On day 6 and 9 of storage, the level of reducing sugar has lowered. This is caused by the respiration process, which uses the reduction sugar as a substrate. The change in sugar reduction levels is consistent with the respiration pattern of fruits. Baldwin (2007) mentioned that on climacteric fruits, respiration would be high at the start of its 


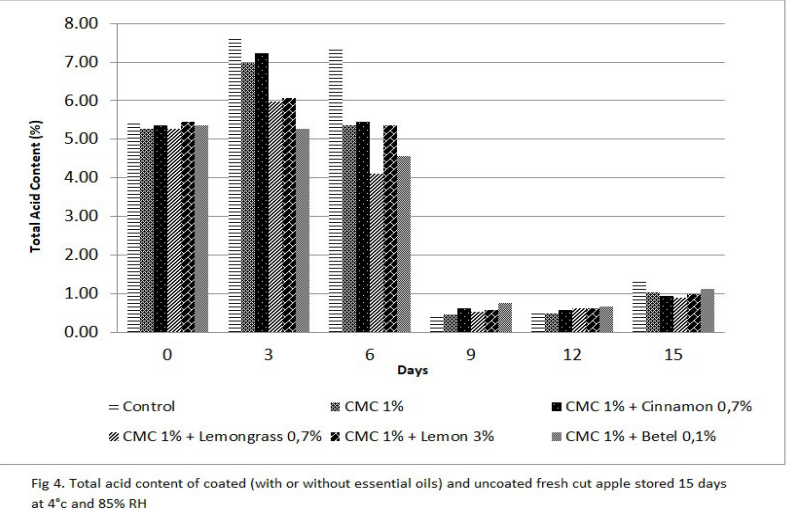

Figure 4. Total Acid Content of Coated (With or Without Essential Oil) and Uncoated Fresh Cut Apple Storage 15 days

shelf-life and would gradually lower proportionate to the storage time.

On day 12, further reduction of reducing sugar levels was observed. This is due to the adapted bacteria's usage of simple sugars on fresh-cut apples as a substrate. Khotimah and Kusnadi (2014) and Ishii et al. (2017) stated that the reduction of glucose levels in fruit was caused by the bacterial activity using the fruit's nutrition as a source of energy and carbon.

On day 15, the reducing sugar levels across all treatments experienced a rise. This increase in reducing sugar levels is attributed to starch-dissolving enzymes caused by the growth of bacteria. The addition of $1 \%$ CMC edible coating on fresh-cut fruit is proven to reduce the rate of hydrolyzed starch that becomes reducing sugar, which is used as a substrate on the respiration process. On the control sample, the rate of starch hydrolysis was high.

\section{Total acid content}

The total acid content of the samples experienced fluctuations from the start of the treatment until the end of the experiment. On day 0 to day 3 , all treatment experienced an increase in total acid content. On day 6 to day 9 , the total acid content decreased, and another increase was observed at day 12 through 15 of storage. The total amount of acid shows the general respiration pattern of climacteric fruits (Figure 4).

Apple is a climacteric fruit meaning that the fruit still experiences respiration after it has been harvested. Climacteric fruits tend to have a higher respiration rate at the start of its shelf-life which slows down at the ripening stage state. However, during the ripening process, respiration rate increases, then goes back down (Kader 2002).

On the third day of the observation, total acid content increased. This is in line with the variable of reducing sugar, where respiration will quicken after the wounding process. It is surmised that the climacteric peak of fresh-cut apples occured on the third day of observation.

On the sixth and ninth day of the observation, a reduction in total acid content was observed. The pace of respiration slows down after acclimatization occurs. Baldwin et al. (1996) mention that in climacteric fruits, respiration experiences an increase at the start of storage and goes down proportionate to the shelf life.

On day 12 and 15, a minor increase in total acid content occurred. This is due to the fermentation process of bacteria in the fresh-cut apples. The bacteria in these fresh-cut apples are assumed to be lactic acid bacteria which produce lactic acid, acetic acid, ethanol, mannitol, dextran, ester, and carbon dioxide as the output of their metabolism. These substances may increase the total acid content of fresh-cut apples.

The analysis of total acid content is often linked to the fruit's respiration rate because of organic acids forming such as citric acid, malic acid, fumaric acid, and succinic acid during TCA cycle in respiration process. Treatment of $1 \% \mathrm{CMC}$ reduced respiration rate of fresh-cut apples (Nisperos-Carriedo 1994) because CMC reduced oxygen absorption without increasing carbon dioxide content on fruit tissue. A low oxygen content or high carbon 


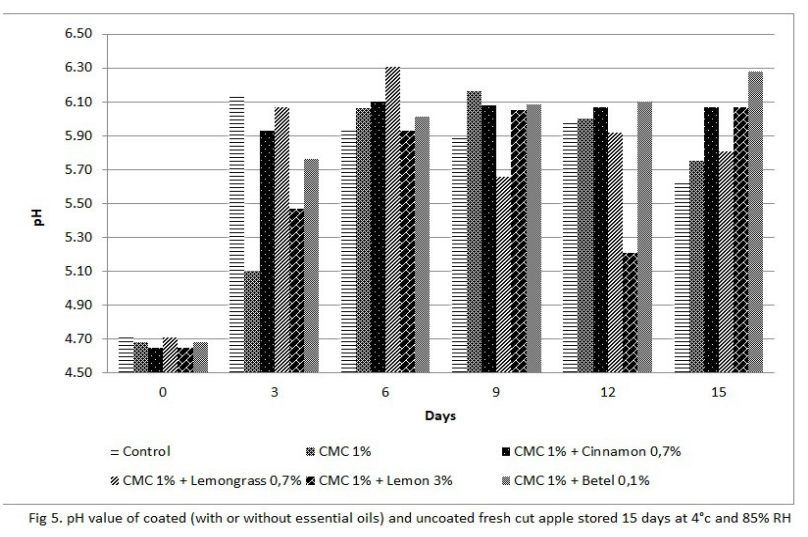

Figure 5. pH Value of Coated (With or Without Essential Oil) and Uncoated Fresh Cut Apple Storage at $4{ }^{\circ} \mathrm{C}$ and $85 \% \mathrm{RH}$

dioxide content delays the synthesis of enzymes that increase the respiration rate therefore slowing down the respiration rate.

\section{pH value}

The bacterial growth rate on the medium is affected by its environment, including its $\mathrm{pH}$ level (Fadlilah et al. 2013). On low pH rating, the cells' membranes are full of hydrogen ions that limits the membrane's transport capabilities. Toxicity caused by low $\mathrm{pH}$ is due to part of the acid substance unable to be absorbed into the cell, which causes ionization and change in the cell's $\mathrm{pH}$.

According to the $\mathrm{pH}$ (Figure 5), the $\mathrm{pH}$ detected on apples are still optimal for lactic acid bacteria (LAB) activity, around 5-6. According to Nannen and Hutkins (1991), LAB can withstand conditions of $3.2-9.6 \mathrm{pH}$ levels. The optimum $\mathrm{pH}$ level for LAB activity is around 3.8 meaning that the addition of $\mathrm{CMC}$ and essential oil treatments cannot inhibit bacterial growth $\mathrm{pH}$-wise

\section{Sensory Analysis}

According to the appearance organoleptic testing from the panellist's opinions, the most favored treatment is $1 \% \mathrm{CMC}+3 \%$ Lemon, while the least favored treatment is $1 \% \mathrm{CMC}$ with $0.1 \%$ Lemongrass. The panellist's judgments are based on the fresh-cut apples' appearance factors including the browning level. When cut and peeled, the fruit will turned brown. Browning on apples is caused by the Polyphenol Oxidase enzyme or PPO. More specifically, the browning process occurs when the phenol substances in apples interact with the polyphenol Oxidase enzyme in the presence of oxygen. The browning process in apples and peaches is related to the chlorogenic acid (Adams and Brown 2007).

The panellists preferred the CMC 1\%+3\% lemon treatment due to its minimum browning level compared to other treatments. Lemons have a high citric acid level, up to $8 \%$ when dry (Penniston, Nakada et al. 2008). Citric acid can bind oxygen and prevents browning on fruit. It is intermediate form of organic acids enable to enhance copper ions, which acts as a catalyst for browning reaction. In addition, citric acid can inhibit browning by lowering the system's $\mathrm{pH}$ level which turns the polyphenol oxidant enzyme inactive (Pizzocaro, Torreggiani et al. 1993).

Flavor is a parameter directly measured by the human sensors to see the fruit's freshness. When a fruit contaminated by microorganisms, the fruit's flavor turns pungent. According to table 3, the most favored treatments on the last day of observation are 1\% CMC + 0.7\% Betel and 1\% CMC + $3 \%$ Lemon. On both treatments, $66.7 \%$ of panellists liked the treatment and the remaining 33.3\% of panellists did not like it. In addition, the least favored treatment is $1 \% \mathrm{CMC}+0.1 \%$ Lemongrass, where $100 \%$ of the panellists did not like its flavor due to its distinct flavor of lemongrass essential oil caused by chavicol acid.

\section{CONCLUSION}

The application of edible coating made from CMC 1\% prolonged fresh-cut apple shelf life compared to the control sample. The addition of $0.7 \%$ lemongrass essential oil produced the best 
result in reducing bacterial growth and prolonging storage life. Treatment of 1\% CMC with addition of $3 \%$ lemon performed the best effect in delaying the browning in fresh-cut apples.

\section{ACKNOWLEDGEMENTS}

The authors thanks Universitas Muhammadiyah Yogyakarta and Ministry of Research, Technology, and Higher Education for the funding and assistance to conduct the research.

\section{REFERENCES}

ADAMS, J. And H. BROWN 2007. Discoloration In Raw And Processed Fruits And Vegetables. Critical Reviews In Food Science And Nutrition 47(3): 319-333

BAKKALI, F., S. AVERBECK, D. AVERBECK And M. IDAOMAR 2008. Biological Effects Of Essential Oils-A Review. Food And Chemical Toxicology 46(2): 446-475

BALDWIN, E., M. NISPEROS, X. CHEN And R. HAGENMAIER 1996. Improving Storage Life Of Cut Apple And Potato With Edible Coating. Postharvest Biology And Technology 9(2): 151-163

BALDWIN, E. A. 2007. Surface Treatments And Edible Coatings In Food Preservation. Pp. 477-498. Handbook Of Food Preservation. S. M. Rahman. CRC Press., Boca Raton, FL. USA: Pp. 1068

BRECHT, J. K. 1995. Physiology Of Lightly Processed Fruits And Vegetables. Hortscience 30(1): 18-22

BURT, S. 2004. Essential Oils: Their Antibacterial Properties And Potential Applications In Foods-A Review. International Journal Of Food Microbiology 94(3): 223-253

CARVALHO, R. L., M. F. CABRAL, T. A. GERMANO, W. M. DE CARVALHO, I. M. BRASIL, M. I. GALLÃO, C. F. H. MOURA, M. M. A. LOPES And M. R. A. DE MIRANDA 2016. Chitosan Coating With Trans-Cinnamaldehyde Improves Structural Integrity And Antioxidant Metabolism Of Fresh-Cut Melon. Postharvest Biology And Technology 113: 29-39

CASIDA, L. E. 1968. Industrial Microbiology. New Age International, New Delhi, 460p

CAVA-RODA, R. M., A. TABOADA-RODRÍGUEZ, M. T. VALVERDEFRANCO And F. MARÍN-INIESTA 2012. Antimicrobial Activity Of Vanillin And Mixtures With Cinnamon And Clove Essential Oils In Controlling Listeria Monocytogenes And Escherichia Coli 0157: H7 In Milk. Food And Bioprocess Technology 5(6): 2120-2131

DASHIPOUR, A., R. KHAKSAR, H. HOSSEINI, S. SHOJAEE-ALIABADI And G. KIANDOKHT 2014. Physical, Antioxidant And Antimicrobial Characteristics Of Carboxymethyl Cellulose Edible Film Cooperated With Clove Essential Oil. Zahedan Journal Of Research In Medical Sciences 16(8): 34-42

DATTA, A., S. GHOSHDASTIDAR And M. SINGH 2011. Antimicrobial Property Of Piper Betel Leaf Against Clinical Isolates Of Bacteria. International Journal Of Pharma Sciences And Research 2(3): 104-109

FADLILAH, U., T. SETYAWARDANI And S. WASITO 2013. The Ef- fect Of Different Ripening Time On Acidity (Ph), Number Of Microorganism, And Lactic Acid Bacteria Of Goat's Milk Cheese (Pengaruh Lama Pemeraman Yang Berbeda Terhadap Keasaman (Ph), Jumlah Mikroba Dan Bakteri Asam Laktat Keju Susu Kambing). Jurnal Ilmiah Peternakan 1(1)

GARDJITO, M. And Y. R. SWASTI 2017. Postharvest Physiology Of Fruits And Vegetables (Fisiologi Pasca Panen Buah Dan Sayur). UGM Press, Yogyakarta, 274p

GUERREIRO, A. C., C. M. GAGO, M. L. FALEIRO, M. G. MIGUEL And M. D. ANTUNES 2015. The Use Of Polysaccharide-Based Edible Coatings Enriched With Essential Oils To Improve Shelf-Life Of Strawberries. Postharvest Biology And Technology 110: 51-60 HARKER, F. R., F. A. GUNSON And S. R. JAEGER 2003. The Case For Fruit Quality: An Interpretive Review Of Consumer Attitudes, And Preferences For Apples. Postharvest Biology And Technology 28(3): 333-347

HOLT, J. G., N. R. KRIEG, P. A. SNEATH, J. T. STALEY And S. T. WILLIAMS 2000. Bergey's Manual Of Determinate Bacteriology. Lippincott Williams \& Wilkins, Philadelphia, PA 19106 USA, 754p

HORWITZ, W. 2000. Official Methods Of Analysis Of AOAC International

INNA, M., N. ATMANIA And S. PRISMASARI 2010. Potential Use Of Cinnamomum Burmanii Essential Oil-Based Chewing Gum As Oral Antibiofilm Agent. Journal Of Dentistry Indonesia 17(3): 80-86

ISHII, M., Y. MATSUMOTO, S. NISHIDA And K. SEKIMIZU 2017. Decreased Sugar Concentration In Vegetable And Fruit Juices By Growth Of Functional Lactic Acid Bacteria. Drug Discoveries \& Therapeutics 11(1): 30-34

JO, W.-S., H.-Y. SONG, N.-B. SONG, J.-H. LEE, S. C. MIN And K. B. SONG 2014. Quality And Microbial Safety Of 'Fuji'apples Coated With Carnauba-Shellac Wax Containing Lemongrass Oil. LWT-Food Science And Technology 55(2): 490-497

KADER, A. A. 2002. Postharvest Technology Of Horticultural Crops. University Of California Agriculture And Natural Resources, 535p

KHOTIMAH, K. And J. KUSNADI 2014. Antibacterial Activity Of Probiotic Date Fruit (Phoenix Dactilyfera L.) Beverages Using Lactobacillus Plantarum And Lactobacillus Casei (Aktivitas Antibakteri Minuman Probiotik Sari Kurma (Phoenix Dactilyfera L.) Menggunakan Lactobacillus Plantarum Dan Lactobacillus Casei). Jurnal Pangan Dan Agroindustri 2(3): 110-120

LOPEZ-ROMERO, J. C., H. GONZÁLEZ-RÍOS, A. BORGES And M. SIMÕES 2015. Antibacterial Effects And Mode Of Action Of Selected Essential Oils Components Against Escherichia Coli And Staphylococcus Aureus. Evidence-Based Complementary And Alternative Medicine 2015

MAIZURA, M., A. FAZILAH, M. NORZIAH And A. KARIM 2007. Antibacterial Activity And Mechanical Properties Of Partially Hydrolyzed Sago Starch-Alginate Edible Film Containing Lemongrass Oil. Journal Of Food Science 72(6)

NAMBIAR, V. S. 2012. Potential Functions Of Lemon Grass Cymbopogon Citratus In Health And Disease. International Journal Of Pharmaceutical \& Biological Archive 3(5).

NANNEN, N. L. And R. W. HUTKINS 1991. Intracellular Ph Effects In Lactic Acid Bacteria1. Journal Of Dairy Science 74(3): 741-746 NISAAÂ, U. And A. DARJONO 2018. Analisis Minyak Atsiri Serai 
(Cymbopogon Citratus) Sebagai Alternatif Bahan Irigasi Saluran Akar Gigi Dengan Menghambat Pertumbuhan Enterococcus Faecalis. Majalah IImiah Sultan Agung 49(124): 59-68.

NISPEROS-CARRIEDO, M. O. 1994. Edible Coatings And Films Based On Polysaccharides. Edible Coatings And Films To Improve Food Quality 1: 322-323

OLIVAS, G., D. MATTINSON And G. BARBOSA-CÁNOVAS 2007. Alginate Coatings For Preservation Of Minimally Processed 'Gala'apples. Postharvest Biology And Technology 45(1): 89-96

PENNISTON, K. L., S. Y. NAKADA, R. P. HOLMES And D. G. ASSIMOS 2008. Quantitative Assessment Of Citric Acid In Lemon Juice, Lime Juice, And Commercially-Available Fruit Juice Products. Journal Of Endourology 22(3): 567-570

PERDONES, A., L. SÁNCHEZ-GONZÁLEZ, A. CHIRALT And M. VARGAS 2012. Effect Of Chitosan-Lemon Essential Oil Coatings On Storage-Keeping Quality Of Strawberry. Postharvest Biology And Technology 70: 32-41

PIZZOCARO, F., D. TORREGGIANI And G. GILARDI 1993. Inhibition Of Apple Polyphenoloxidase (PPO) By Ascorbic Acid, Citric Acid And Sodium Chloride. Journal Of Food Processing And Preservation 17(1): 21-30

PONCE, A. G., S. I. ROURA, C. E. DEL VALLE And M. R. MOREIRA 2008. Antimicrobial And Antioxidant Activities Of Edible Coatings Enriched With Natural Plant Extracts: In Vitro And In Vivo Studies. Postharvest Biology And Technology 49(2): 294-300

PRAKASH, B., R. SHUKLA, P. SINGH, A. KUMAR, P. K. MISHRA And N. K. DUBEY 2010. Efficacy Of Chemically Characterized Piper Betle L. Essential Oil Against Fungal And Aflatoxin Contamination Of Some Edible Commodities And Its Antioxidant Activity. International Journal Of Food Microbiology 142(1-2): 114-119

RAEISI, M., H. TAJIK, J. ALIAKBARLU, S. H. MIRHOSSEINI And S. M. H. HOSSEINI 2015. Effect Of Carboxymethyl Cellulose-Based Coatings Incorporated With Zataria Multiflora Boiss. Essential
Oil And Grape Seed Extract On The Shelf Life Of Rainbow Trout Fillets. LWT-Food Science And Technology 64(2): 898-904

RAYBAUDI-MASSILIA, R., J. MOSQUEDA-MELGAR, R. SOLIVA-FORTUNY And O. MARTíN-BELLOSO 2016. Combinational Edible Antimicrobial Films And Coatings. Pp. 633-646. Antimicrobial Food Packaging. J. B.-V. (Eds.). Elsevier: 676p

RAYBAUDI-MASSILIA, R. M., J. MOSQUEDA-MELGAR And O. MARTíNBELLOSO 2008. Edible Alginate-Based Coating As Carrier Of Antimicrobials To Improve Shelf-Life And Safety Of Fresh-Cut Melon. International Journal Of Food Microbiology 121(3): 313-327

SABA, M. K. And O. B. SOGVAR 2016. Combination Of Carboxymethyl Cellulose-Based Coatings With Calcium And Ascorbic Acid Impacts In Browning And Quality Of Fresh-Cut Apples. LWT-Food Science And Technology 66: 165-171

SALMIERI, S. And M. LACROIX 2006. Physicochemical Properties Of Alginate/Polycaprolactone-Based Films Containing Essential Oils. Journal Of Agricultural And Food Chemistry 54(26): 10205-10214

SOMOGYI, M. 1952. Notes On Sugar Determination. Journal Of Biological Chemistry 195: 19-23

STONE, H., R. BLEIBAUM And H. A. THOMAS 2012. Sensory Evaluation Practices. Academic Press, 436p

VAZIRIAN, M., S. T. KASHANI, M. R. S. ARDEKANI, M. KHANAVI, H. JAMALIFAR, M. R. FAZELI And A. N. TOOSI 2012. Antimicrobial Activity Of Lemongrass (Cymbopogon Citratus (DC) Stapf.) Essential Oil Against Food-Borne Pathogens Added To CreamFilled Cakes And Pastries. Journal Of Essential Oil Research 24(6): 579-582

VU, K., R. HOLLINGSWORTH, E. LEROUX, S. SALMIERI And M. LACROIX 2011. Development Of Edible Bioactive Coating Based On Modified Chitosan For Increasing The Shelf Life Of Strawberries. Food Research International 44(1): 198-203. 